て，いち早く買いに行ったのは,こんな悪たれをきくた めでないことも確かである。
いってしまえば，胸がスーッとするかと思ったが，ど うもあと味の悪いことになった。ドギツイ表現でないと， 思ったことがいえなかったことを恥じいるしだいである.

\title{
日本における近代科学の受容と意義
}

「日本に抢ける近代科学の受容と意義」に関するシンポジウムが，日本学術会議科学史・科学基礎 論研究連絡委員会主催のもとに 1961 年 9 月 30 日（土曜日)，13 時 30 分〜17 時に，日本学術 会議講堂に扔いて開催された。

科学史の方から，横浜市立大学教授

三枝 博音氏

基礎論の方から，東京教育大学教授

下村 寅太郎氏

の二氏の講演があった．要旨は下に記したと扤りであ る.

な扔，両氏の講演は，要旨に手を入れたものであっ た.

\section{1 日本に於ける近代科学の容受と意義}

$$
\text { 三枝 博 音 }
$$

いっぱんに科学ということになれば，西欧からの受容 いぜんに执いてでも，日本にも科学はあったといわねば ならない，しかし，近代科学ということにな机，これ はまったく外国からの受容にまたねばならなかった。そ うしてみると，受容の意義はまことに大きいといわね棯 ならない。

このことを考えてみるには，もし西欧から近代科学を 受容しなかったなら，日本の文化はどうだったろうか？ という問い方をしてみるのがいい，さて，そういう問い 方をするには，まず日本人は，近代になっても近代科学 を経験しないまつに過ぎていられたのだということを仮 定せ齐ばならない，この仮定は（近代科学を経験しない で近代を経過した民族や国民はいくらもあったのだか ら）十分みとめられる.

さて，日本の科学史のなかで近代科学がはじまりだし たといえるのは，安永年間である，だから 1770 年いご

$$
\text { この講演にたいして. }
$$

湯浅 光朝 科学史・神戸大学教授

山内 恭彦基礎論・東京大学教授

板倉 聖宣 科学史・国立教育研究所員

広重徹科学史・日本大学講師

弥永 昌吉 基礎論・東京大学教授

佐藤 七郎 科学史 $\cdot$ 東京大学助手

大江 精三 基礎論・日本大学教授

の七氏の特定発言者の発言がありここのも一時間に わたって討論が行われた。

でも，日本は近代科学なしにでもやってこれたというこ とを，仮定してみることができる，近代科学なしにやっ てきたとしたら，日本人は日本文化の発展に扮いて，ど ういう損失を招いたことになったであるうか。

さて，日本文化はどういう点で損失をうけたかという ことをたずねるには，近代科学があるとは内容上どうい うことなのであるか，いつかえれば日本人の文化におい てどういう方がいがあったろうかというように追求して みればよい。

日本に扔ける近代科学いぜんの科学は，中国の儒教思 想につ〉まれていた自然哲学的な学問か，それともここ れに南蛮紅毛の学問のなかにあったアリストテレス的形 而上学からぬけ出ていない自然哲学が加わったりのかで あった。それは具体的にいうと，天文学では（17 世紀 後半から 18 世紀前半のころには) 井口常範の『天文図 解』や中村惕斎の『天学考要』のような科学知識, 医学 では吉益東洞いぜんの李朱医学のそれのようなものや， クリストヴァオ・フェッレイラ（沢野忠庵）の『乾坤弁 説』や国の遊子六の『天経惑問』系統の知識のような ものである. 近代科学移入いぜんでは, 科学とは自然科 学というよりも自然哲学であったてそして，それは主と して天文学，医学，航海学などにとどまるものであった。 
日本の近代において近代科学がなかったとすれば，右に あげたような医学や天文学の知識だけで済まして居ら权 ばならなかった、したがって, 近代科学ありとは, 形而 上学的な自然哲学の思弁にまかせないで, 自然を, すな わち医学では陰陽医とちがって人体のなかの疾病そのも のを観察と実験の対象にする. 天文学では性命の天文学 とちがって天体そのものの観測と記述に学的努力を集中 する、航海学でいうなら，たとえば思弁に支配された方 針盤（24 方針）によるのでなくて 32 方針盤によるよう な航海の学術を重んずる，ことなどである.

近代科学なしにやっていけたということは，こつにい うところの近代科学ありの反対であることである，具体 的にいえば, 病気の治療はいわゆる仙家や陰陽医の手中 に置くことであり，天文学では星列の関係を人間生活の 吉凶の判断に固く結びつけておくことであり, 地球の海 の上を航海するのに獣带 (十二宮) という旧い天文知識 に固執することである.

近代科学なしにやっていくということは，日本人の文 化の発展に㧊いて，ぞういう損失を招くかは，以上の指 摘だけで明らかであろう。日本は近代になっても近代科 学なしにやっていけたことであろう。つまり 1770 年こ ろからいごに执いても, 日本人の科学的知識は形而上学 的思弁だけだったろう。したがって日本人ぜんたいの厚 生は野蛮のま〉であり, 産業は合理的に発展できず, 日 本人の力量による海外との交通は不可能のまつであった ことであろう。しかし，全損失は，これらの指摘たけで はまだ十分明らかにならない，むしろ，天文や医学や航 海学やが形而上学的思弁のなかに閉じこめられ不毛のま つであることは, 日本人の政治思想と経済知識をどこま でも根強く封建性の暗さのま〉で置くことである. 近代 科学のこの恐るべき遅齐のままが，もし世界史のめざま しい発展の時期すなわち 18 世紀後半から 19 世紀にお ける近代国家形成の一応の完成の時期までのばされたと したならば，日本という民族国家は，いと容易に当時 の帝国主義的植民地化のもとに，置かれたことであろう． そして今日現にみるような日本の文化は到底形成されな かったであろうことは，容易に推断されるのである．

しかるに，事実はそうでなくて，安永年間（1772～ 1781 年）いごではたしかに日本の科学は近代性を具え はじめたのであった。たとえば，1774 年の『解体新書』， 同年の本木良永が地動説をつたえた『天地二球用法記』， 75 年の三浦梅園の『玄語』, 81 年のニュートンの引力論 のつたえられた志筑忠雄の『求力諭』，また间年の良永
の『オランダ海鏡書』(緯度のみでなく経度も論じられ 太陽視差の計算や羅針盤の紹介やが含まれていた）など の成立.すでに天文学では，和蘭わたりの天文台が設け られていたことなど. 医学や天文学や航海学の新知識が 入ってきて蘭学を通じて近代科学の知識が受容されはじ めた.この安永年間の近代科学の知識の受容は，寛政時 代（1789１800 年）に扔いて開化結実している．とい うのは, 『暦貨新書』の忠雄は良永に影響され，観察・ 実験・記述の近代的自然科学の方法を実現しはじめた麻 田剛立は梅園に刺载され影響され，さらに剛立の科学か ら高橋至時や間重富，つぶいて伊能忠敬が出てきている から. 以上は 18 世紀後半から 19 世紀の初頭のことで ある. 物理学 (この科学は気の科学として日本に現われ たが）や化学や植物学や病理学などが，受容されたのは 19 世紀の前半に扔いてぶあったが，近代科学の諸学科 がこのように形をそろえて現われたのは，18 世紀後半 の和蘭科学の受容の持続に外ならなかった。幕末に扣け る洋学所, 蕃書調所, 洋書調所, 開成所, 医学所その他 の科学研究の施設の実現も, こ〉にいう持続であり, 発 展に外ならない, 維新の変革の後, 明治政府が大学や調 查研究の機関を設けて近代科学の受容が制度的に確実に なり得たのも，江戸時代の後半に打ける以上述へた如き， 和蘭文化の受容を通じて実現したのでなくてはならない， 以上，私は日本では近代科学の西欧からの受容の基礎 が江戸時代の後半にできたものと解しもしこれが実現 しなかったならば，日本は今日人々が低開発国と呼んで いる諸国のような運命をたどっていたにちがいないとい うことを述へたが，以上の主旨で，るっと詳しく他の機 会にこの問題（日本に於ける近代科学の受容と意義）を 考察してみたいと招もう。

\section{2 日本における近代科学の 受容とその意義}

下村 寅太郎

筆者は日本科学史については，ディレッタントにす ぎない、唯戦時中, 桑木或雄博士を代表者とする明治 科学史の協同研究会に名を連らねたことがある.その 後, 関心が移易して, 最近のこの方面の学界の消息に 全く昏い，小渝は往件の想念に甚づくものにすぎない のであって，固より程極的な意兄を提出する意図はな 
い、寧ろ卒直に疑問を述べて専門家の教示を期待する ものにすぎない.

近代科学の受容という場合, 先ずこの「近代科学」の 意味が問題である. 通常, 日本に扔ける近代科学の受容 の歷史は「籣学」から始められる.（それ以前の「南蛮 学」と称せられたものについては暫く措く).こ〉で先 ず第一に，「蘭学」という名称自身に予想されている「科 学」の概念が問題であろう。それは必ずしも近代科学で はない. 少くとも問題的である.「蘭学」という概念は 「国学」「漢学」に対する「蘭学」である．従来の伝統 的な学問と系譜を異にする単に別個の学問として受けと られている. それは確かに伝統的な学問に対しては別個 のものであり，その意味では，新らしい学問であった。 しかし「新らしい」ということは必ずしも「近代的」と いう意味ではない，伝統的な学問に対して特に䒜新的な 学問という意味での新らしい学問として受けとられては いない.

そもそも「近代」あるいは「近代的」という概念は日 本の歴史には本来的なものではない.いうまでもなく西 欧の歴史に扔いて成立し形成された概念で，古代・中 世・近代はそれぞれ独自な内容と性格をるち, 近代は単 に「古い」時代に対する「新らしい」時代の意味ではな い. 中世を否定し，それとは“epoch”を劃するという 自覚的な革新的意識においての「近代」であった。「近 代科学」る正にかつる「近代」そのものの独自な科学で あった、単に「近代に扔ける科学」ではない.「近代」 の意識と共に, むしろ近代の意識によって成立した科学 である.しかし日本人が受容した西欧の科学は，日本人 にとっては確かに新らしい学問であったとしても，その 新らしさは単に新奇という性格のものでしかなく，古い 伝統的な学問を否定する「新」科学ではない、新来の科 学を「策学」と呼び, 新らしい科学者としての䉒学者が 実際にこれに臨んだ仕方や態度に扔いてこのことが認め られるであろう。

周知のように, 蘭学は最初, 長崎の通詞によって行わ れたが，しかし彼らは本来通訳官商務官であって，蘭学 はその余技又は副職にすぎず，固よりディレッタント以 上のものではない.これが専門学者による学問としての

「蘭学」になったのは, 江戸に扔ける前野良沢, 杉田玄 伯, 中川淳庆らの『解体新書』の眽訳以来のことである. こ〉で始めて闌兴は絜人の好事から学者の仕事となった。 ところでこ机らの蘭学者はすべて医学者であり,すべて
熯学を基本的教養としている.このことはながく変るこ とはなかった、漢学は，しかし，単なる語学ではない， 儒教的倫理・形而上学を実質とする学問である，蘭学者 はこの漢学を決して否定せず，捨ててはいないのである. その必要を意識していない. かかる蘭学が近代科学であ り得るかが我々の問題なのである.

更に注意さるべきことはここれらの蘭学者がすべて医 学者であったこと, 医学が出発点であったことである. 単に出発点に扔いてそうであっただけでなく，永く医学 者がその中心であったことは，幕末から明治の始めに到 るまで, 例えば兵学者大村益次郎も, 福沢諭吉の如き人 すら，蘭学を学ぶために大阪の医学者緒方洪庵の門人に ならねばならなかったことを想起するだけで十分であろ う. 蘭学が医学を出発点とし, 医学を通して理解された ことは, 蘭学が果して近代科学であったかの問題に対し て更に実質的に重要な問題を含んでいる。蘭学が単に 「新」科学——新奇な科学であって革新的科学として意 識されていたかが問題であるだけでなく，この新科学の 理解の仕方そのものがこ〉で問題になる.

医学に扔いて，或は医学を通して理解された科学では， 科学の理解の仕方に本質的な制約がある.これは近代科 学の理解は固より，一般にョーロッパの「科学」そのも の〉理解に対して問題である. それは科学の理念と方法 の理解に対して根本的な制約をなすといってよい.

西洋の科学は, 古代ギリシャの場合でも, 近代でも, 宎文学が先駆をなす. 天文学は単に科学の先駆であった だけでなくその模範になっている．そのことは西欧の科 学の性格或は理念を規定するものである. 即ち天体の運 動の規則正しさの発見を通して世界に扔ける法則性の実 存を自覚し，それの探究を科学の究極目標としている. そうして特にョーロッパの科学の性格的特色として重要 なことはその法則性が数学的なそれであることである. 世界の数学的法則性の探究が西洋の一一古代と近代とを 間わず一科学の根本理念である. 医学の場合にはこの 理念は必ずしも顕著ではない（このことは勿論科学史 に扔ける医学の役割を低く評価するということではない. ギリシャ科学に扔いても近代科学に扔いてもそれの成立 に医学が重要な役割を演じていることは周知のことであ る. 我々の問題にするのは, 科学の理念の理解に関して の医学の役割である. 医学或は医学者が先駆をなした蘭 学に扔いてこの科学の理念と方法が果して十分に把握さ れたかを問題にするのである。）このことは蘭学者とし ての医学者が依然として漢学を根本教荃としそれの根底 
にある㓌陽五行の如き東洋的伝統的な形而上学に対して 必ずしも根本的な対決をしていないことが近代科学の理 解という点に関して重要な問題を含んでいると言ってよ いであろう．医学者は明治に到るまで僧形をしていたこ とを一つの象徵的なものとして想起してよいであろう. 物理学者・天文学者としての蘭学者に㧊いても, 儒学・ 漢学が基礎教養であったことには変りはない，そうして 漢学は決して単なる言語学ではないのである.

第三に, 特に近代科学の受容には，それの根本的性格 としての実験的方法が重要な問題である.これは単に実 験が行われたか否かの問題ではない，実験的方法の根底 に予想されている認識の仕方一一正に近代科学が革新的 である所以のもの一の意義が自覚され把握されていた かが正に問題である. 論証的方法に対して実験的方法が 積極的に意欲した認識の理念, 即ち既知の知識の証明で なく未知の知識の発見の方法であることが意識されてい たかである. 単に実験するのでなく発見の方法, 更に, 専ら実験によって見出されるものに真理の拠り所を認め, 実験によって知られたものをのみ真理とする意識の有無 である.もしこれらのことがなければ，これは単に既成 の新奇な知識の受容というだけで，仮令それが内容的に は近代科学に属するものであっても，必ずしも直ちに近 代科学の受容というに足りない．少くとも本質的には問 題である。その意味に扔いて, 近代科学の受容は, 悠密 には，明治に扔いて，即ち大学の成立以後のことではな いであろうか．明治以前の科学と明治以後のそれとの間 には必ずしも連続性が存しないのではないか。 あたかも 和算と明治以後の数学とが連続的でないのと同じような 状況が存するのではないか.

実際に，明治以前の蘭学者として総称される，科学者 の仕事は先ず和蘭語の学習であった，而もこれに大いな る精力が費されている．寧ろ実質的には蘭学者の仕事は 蘭書の読解・註解・燔訳とそれの試行的実施にあったの ではないか，積極的な科学的研究がいかなる程度になさ れたかは問題ではないか（たとえニュートンの体系が
麻田剛立らの著作の中に含まれていても本質的には変ら ない）その意味では蘭学者は科学者であるよりは寧ろ 文献学者であったのではないか.この事情はルネッサン スの所謂科学者に似ている. 彼らにおいては古代ギリシ ヤの科学的文献の研究が即ち科学研究であった．新らし い古代文献の発見が同時に新らしい科学的知識の発見で あった. 彼らにとってそれは決して歴史的研究ではなか った・ガリレイ，ケプラーらによる「近代科学」はその 後の段階のことであった．それと相似的なものが我々の 闌学時代の近代科学の受容に扔いて認められる。仏教や 儒教の倫理的形而上学的なものから自由になった「科 学」, 蘭学・英学・独学・仏学でない単なる科学, 普遍 的な科学の自覚は明治以後に属するのではないか. 固よ りこれらのことは歴史的過程として必要な段階であって， それ自身に揖いては歷史的重要性をるつことは言うまで もない.

しかし, 明治になって始めて伝統的な形而上学から自 由なる「近代科学」が自覚的に受容されたとしても, 同 時にこの metaphysikfrei は空虚な Freiheit であっ $\tau$, 寧ろ metaphysiklos な科学, 単に特殊的専門的技 術的な科学にすぎないものではなかったであろうか. 古 代ギリシャ科学は固より，「形而上学から自由なる」近 代科学と雖も, 総じて西欧の科学の基礎となっている世 界の合法則性・合理性という体系的思想, 合理主義的世 界観を，その意味での「哲学」をもたない，少くともそ れとのつながりをもたない，単に技術的性格のものでは なかったであろうか. その意味で単に科学的技術の受容, 或は少くとも科学の技術的受容に止ったのではないであ ろうか. それは末た科学の歴史性の理解をもたない. 単 に科学の結果たけの受容, 結果としての方法だけの受容, 結局，科学の技術的受容ではなかったであろうか. 勿論, これは一般的概括的に言われ得ることであって，固より 個々の科学者に扔いて例外の存したことは，歴史的事実 である。例外のない歴史はない。

(61. 9. 31) 